\title{
Relationships Between Trust And Collaborative Culture In The Context Of Tacit Knowledge Sharing
}

\section{Wioleta Kucharska ${ }^{1}$}

\begin{abstract}
The literature review presents a lot of theoretical and empirical evidence that trust affects collaborative culture. The opposite also proves to be true: collaborative culture influences trust. The main hypothesis presented in this paper says that both these factors are strongly correlated and modify each other. This study examines the mutual relationship of the said variables in the context of tacit knowledge sharing based on research conducted among 514 Polish professionals performing different functions, and having various experience in managing projects, in the construction industry. The results obtained in the course of the study indicate that there is not only a strong correlation between trust and collaborative culture but both of them have a strong influence on tacit knowledge sharing. The main managerial implication of the study is the importance of stimulating the growth of both collaborative culture and trust. receiving a strong synergy effect will make it possible to leverage tacit knowledge sharing as an agent contributing to a company's performance.

Keywords: trust, tacit knowledge sharing, collaborative culture, project management.
\end{abstract}

\section{INTRODUCTION}

Nowadays, in the network economy, conducting a successful business does not only require a collaboration of individuals but its more advanced form - co-creation. As Becket and Jones (2012) noticed, "as a result, there is now increased emphasis on trust and the important role it plays in ensuring collaboration success." Orchard, Curran, and Kabene (2005) point out that creating a collaborative culture based on a relationship of interdependence, built on respect, trust and understanding, can be beneficial for the final performance of a business. Based on the literature review, we can find a lot of

1 Wioleta Kucharska, Ph.D., Assistant Professor, Marketing Department, Management and Economics Faculty, Gdańsk University of Technology, Narutowicza 11/12 street, 80-233 Gdańsk, e-mail: wkucharska@zie.pg.gda.pl. 
theoretical and empirical evidence that trust affects collaborative culture and that collaborative culture influences trust. Although trust and collaboration often coexist, the two concepts differ markedly (Lefebvre \& Shiba, 2005).

Trust is understood as "the confidence that the reciprocal exchange between two parties will be met with a positive outcome for both" (Lee, Gillespie, Mann \& Wearing, 2010). Perez Lopez, Peon, and Ordas (2004), as well as Barczak, Lassk, and Mulki (2010) define collaborative culture as a "team's shared values and beliefs about the organizations' support for adaptability, open communication, and encouragement of respect, teamwork, risk-taking and diversity." Trust is built on the platform of having information about others, prior ties of working together, standards of cooperation, and sanctions for all who might break norms of behavior. Having an incentive is a necessary, but not an adequate basis for having trust (Harris \& Lyon, 2013).

"Culture has been viewed as an influencing element that impacts the morale of an employee, his motivation and willingness; the level of productivity and effectiveness; the quality of work; innovation and creativity; and the attitude of employees in the workplace" (Campbell, Stonehouse \& Houston, 1999). Collectivism and individualism, as dimensions of culture, represent sets of individuals' beliefs and values concerning the independence from and interdependence among other team members (Alavi \& McCormick, 2007). Furthermore, people high in collectivism orientation tend to put aside their own self-interest in deference to the interest of their group. Conversely, people low in collectivism (i.e., with a more individualistic orientation) tend to put forth and promote their own welfare over the interests of their group (Hofstede, 2001). According to Gray (1989), collaboration is "a process through which parties who see different aspects of a problem can constructively explore their differences and search for solutions that go beyond their own limited vision of what is possible." A collaborative culture reduces competition among employees and increases their willingness to share critical information (Szulanski, 1996). A culture of collaboration and mutual accountability provides an opportunity to end the blame-game cycle, as claimed by Wallace and Mello (2015). In their opinion, collaboration facilitates a proactive process which allows for the creation of shared goals and the development of mutual tasks, and permits more rapid identification of problems, creating a meaningful sense of organizational teamwork. Moreover, they claim that collaborative culture is a culture that, in today's world, businesses cannot afford to live without.

Sharing knowledge by co-workers is essential for organizations. Open sharing of relevant knowledge has the potential to lower costs and optimize processes. The lack of sharing may harm organizations and even render their processes ineffective (Rutten, Blaas-Franken \& Martin, 2016). Polanyi (1966) 
was among the first to classify knowledge as explicit and tacit. Over time, this classification was adopted by others. As opposed to explicit, tacit knowledge is absolutely novel and, for this reason, beneficial for organizations. This form of knowledge is peculiar; it is created and cumulated in a human's mind and, being an intangible asset, it is closely associated to social capital. Intangible assets become increasingly likely to decide on the competitive advantages of companies. They are not easily noticeable and are hard to measure; however, their indirect influence often proves to play a crucial role in value creation. A lot of studies have been dedicated to the general idea of explicit knowledge sharing, but only a few focus on tacit knowledge (Chow, 2012; Kucharska, 2016; Rutten et al., 2016).

Change is a permanent condition for businesses nowadays. In order to implement change successfully, companies run projects in such a way as to achieve the results they desire using the resources they have assigned to a given task (Portny, 2010). A project is an autonomous organization connected to a parent organization (Artto, Kujala, Dietrich \& Martinsuo, 2008). It is a series of tasks with a start and end date, specific goals and conditions, defined responsibilities, a budget, and multiple parties involved. Every project is unique in nature and does not involve any repetitive processes (Yang, 2012). Projects require the close cooperation of all their members.

The first goal of the study is to look at the mutual influence of collaborative culture and trust in the context of tacit knowledge sharing. The second goal is to present the results of empirical research of the study, conducted among 514 Polish professionals with different functions and experience in managing projects in the construction industry, as evidence of this mutual relationship.

\section{CONCEPTUAL FRAMEWORK}

The literature review gives us a lot of theoretical and empirical evidence that trust affects collaborative culture and that collaborative culture influences trust. According to Barczak, Lassk, and Mulki (2010), as well as Park and Lee (2014), Trust has a strong influence on collaborative culture. Kottila and Rönni (2008) claim that collaboration is approached by focusing on communication and trust between the business actors. With respect to the idea of a collaborative network, Berasategi, Arana, and Castellano (2011) claim that "trust amongst all network agents is the cornerstone of collaboration, and therefore there is a demand to promote a collaboration culture based on fostering human relations."

Likewise, Pishdad-Bozorgi and Beliveau (2016) point out the fact that trust creates a collaborative environment. In the opinion of Fawcett, Jones, and Fawcett (2012), breakthrough trust is the catalyst to collaborative innovation. 
Chen, Lin, and Yen (2014) examined that inter-organizational trust leads to better inter-organizational collaboration and knowledge sharing. Referring to online collaborative groups (OCG), Smith (2008) presents moderate trust models and assumes that trust provides conditions under which outcomes such as cooperation and high performance are likely to occur, but he assumes no direct relationship between them.

On the other hand, Lefebvre, and Shiba (2005) claim that collaboration fosters trust. They present a case study of the automotive industry as proof that collaboration can be transformed into trust. Establishing trust-building organizational routines (culture) requires a correct evaluation of a partner's collaborative capability and then measuring a partner performance, as suggested by Fawcett et al. (2012). According to Thomas, Zolin, and Hartman (2009), trust is shaped through collaboration and information sharing. Similarly, as Aramo-Immonen, Jaakkola, and Linna (2011) claim, creating a supportive behavioral base encourages the formation of trust. Wallace and Melo (2015) simply suggest that collaborative culture promotes trust; however, Taormina (2009) heartily points out that trust is an integral part of a collaborative culture.

In the opinion of Pishdad-Bozorgi and Beliveau (2016), true collaboration occurs when individuals trust and respect one another, know that their partners will not take advantage of them and that together they can develop better solutions and results than they would individually. Buvik and Rolfsen (2015), claim that relationships between task participants are built on mutual trust and collaboration. These two factors allow establishing an organizational culture which encourages knowledge sharing. The conclusion is that both these conditions must be met to achieve high performance. Kumar and Paddison (2000) argue also that both trust and collaboration reinforce each other. Based on the arguments above, the following hypothesis was formulated:

\section{H1: Trust and collaborative culture have a strong, positive correlation.}

Trust is an integral part of a collaborative culture and is found as one of the several antecedents of knowledge sharing behavior (Taormina, 2009). Trust is also an important predictor of knowledge sharing, as is claimed by Chen et al. (2014), and it is closely linked to information sharing and exchange (Bachmann \& Inkpen, 2011; Cai, Jun \& Yang, 2010; Cheikhrouhou, Pouly \& Madinabeitia, 2013; Msanjila \& Afsarmanesh 2009, 2011; Thimm \& Rasmussen, 2010). According to Young and Milton (2011), information is a source of knowledge. Research results by Park and Lee (2014) indicate that project team members share knowledge when they can trust one another and feel dependent. Ding, $\mathrm{Ng}$, and Li (2014) pointed out that trust strongly 
influences knowledge sharing in architectural design teams. Kucharska and Kowalczyk (2016) claim that trust has a positive impact on tacit knowledge sharing among project team members. Following the presented research, hypothesis 2 was formulated:

H2: Trust has a positive influence on tacit knowledge sharing.

Trust is needed to deal with the numerous business uncertainties involved. It is considered to have various important benefits for the practices of complex collaboration; it is supposed to facilitate cooperation, to render collaboration more robust, to boost performance and to make innovation possible (Klijn, Edelenbos \& Steijn, 2010; van Oortmerssen, van Woerkum \& Aarts, 2014). Brown, Gray, McHardy, and Taylor, (2015) present a theoretical framework which serves to establish a link between the employee trust and a company's performance. They claim that trust between employees in the workplace influences their behavior, which in turn affects a company's performance and a company's ability to achieve its goals, as was also pointed out by Gilbert and Li-Ping Tang (1998). Although trust is one of the key determinants of employee performance (Paliszkiewicz, 2011) it cannot be considered as a sum of individual performances (Bakotić, 2016). Business partners who reach collaborative trust share resources willingly to help create a greater, unique added value and improve business performance (Fawcett et al., 2012).

Referring to the construction industry, the research findings of PishdadBozorgi and Beliveau (2016) indicate that Integrated Project Delivery (IPD) as a form of close collaboration and trust have a bi-directional relationship. Results by Lau and Rowlinson (2009) and Buvik and Tvedt (2016) suggest that trust affects project commitment and also, directly and indirectly, team performance. Interventions to develop a high trust climate in project teams can thus contribute to improved project performance. Likewise, Mach and Baruch (2015) suggest that team orientation affects project performance mediated by trust. Based on all that was presented above, hypothesis 3 was formulated:

H3: Trust has a positive influence on project performance.

The collaborative orientation of organizational culture is an important implication for knowledge sharing (Greiner, Böhmann \& Krcmar, 2007). With reference to Khalil and Seleim (2010), individuals' knowledge should be shared in groups and teams, and this is crucial for the cultural support of knowledge sharing. For organizations, to gain an advantage of their knowledge-based resources, it is important to propagate a culture that will give preferential 
treatment to knowledge transfer activities (Barratt-Pugh, Kennett \& Bahn, 2013). Joint collaboration could result in rich and nuanced discourse that brings differing degrees of knowledge, insights, and understanding to all participants involved in the project (Rinehart \& Earl, 2016). The significant influence of Collaborative Culture on Knowledge Sharing has also been pointed out by Mueller (2014) and Arpaci and Baloglu (2016), and examined by Kucharska and Kowalczyk (2016). Based on the above, the hypothesis 4 was formulated:

H4: Collaborative culture has a positive impact on tacit knowledge sharing.

Inaam, Abderrahman, and Yasmina (2016) investigated a framework to characterize the financial and non-financial performance of an organization in terms of their collaborative practices. Chow's (2012) study presents that organizational collaborative culture has a direct influence on performance. The qualitative research conducted by Zuo, Zillante, Zhao, and Xia (2014), shows that projects with an integrative, cooperative, flexible, and people-oriented collaborative culture, performed much better than others in most of the dimensions of project outcomes, such as schedule, functionality, satisfaction from the process and relationships, environmental performance, commercial success, further business opportunities, and overall performance. Oyewobi, Abiola-Falemu, and Ibironke's (2016) studies prove the positive influence of organizational culture on high-quality project delivery in the construction industry. In relation to the presented research, hypothesis 5 was formulated:

\section{H5: Collaborative culture has a positive impact on project performance.}

Referring to studies of Hau, Kim, Lee, and Kim (2013) related to the impact of tacit knowledge sharing on explicit knowledge, which according to the research conducted by Park, and Lee (2014) and also Gemino, Reich, and Sauer (2015) has an effect on project performance, leads to the logical conclusion that analogically to general knowledge sharing the sharing of tacit knowledge has a positive impact on project performance. This train of thought is reflected in hypothesis no 6 . As was mentioned in the introduction section, very few researchers have examined tacit knowledge sharing and project performance creation. Studies of Chow (2012), Kucharska and Kowalczyk (2016) confirm that tacit knowledge sharing enhances project performance. Based on their study and all that was mentioned above, the hypothesis 6 as follows was formulated:

H6: Tacit knowledge sharing has a positive impact on project performance.

Figure 1 graphically presents the theoretical model. 


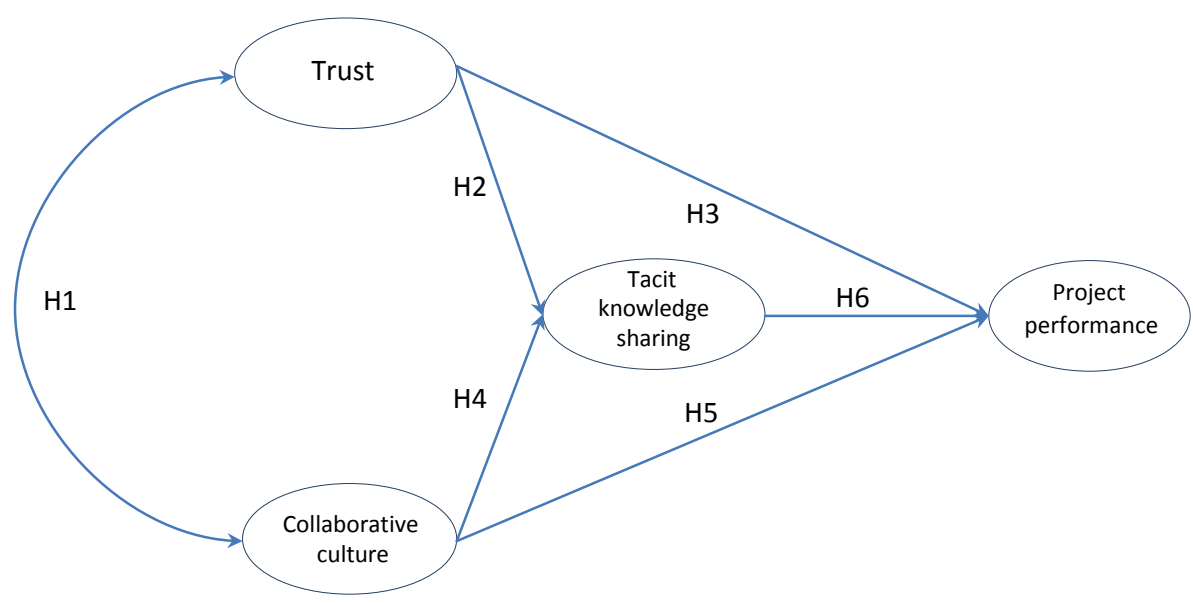

Figure 1. Conceptual framework

Source: author's own study based on Park \& Lee (2014), Arpaci \& Baloglu (2016), Chow (2012), Gemino, Reich \& Sauer (2015), Rinehart \& Earl (2016), Kucharska \& Kowalczyk (2016).

\section{METHODOLOGY}

The study was carried through a questionnaire completed by Polish professionals working in the construction industry. The respondents reacted to statements based on a 7-point Likert scale, which goes from 1 assigned as definitely NOT to 7 assigned as definitely YES. The statements created to match the measurement scales are presented in Table 2 . The questionnaire structure followed a path from general issues to detailed issues which required more precise answers. Thus, it started with a simple introduction explaining the aim and scope of the survey. At first, the qualifying questions strictly referred to the subject matter and regarded the participant's affiliation to any projects. Before running the full survey a preliminary study involving 32 respondents preceded it. The aim of this pilot study was to optimize the statements by ubiquity elimination. The final data gathering took place online, using the "snowball method", and started with managers who then recommended our study to their co-workers. The data were collected from February to April 2016. The sample size was 600 respondents, of which 514 cases were accepted for further analysis, after rejecting invalid forms. The sample comprised of $61 \%$ who were project managers, $16 \%$ team members, $21 \%$ team leaders, $1 \%$ from a steering committee, and $1 \%$ who were project sponsors, all with different experience levels. $98 \%$ of the respondents were 
male and $2 \%$ were female. The analysis was provided using the structural equation modelling method.

According to the theoretical model presented in Figure 1, a measurement model and, later, a structural Confirmatory Factor Analysis (CFA) model were run. Estimation was provided in the reference to a maximum likelihood method (ML). The model quality evaluation was conducted based, at first, on tests such as: Average of Variance Extracted (AVE), Composite Reliability (CR), Cronbach's Alpha, and next: Root Mean Square Error of Approximation (RMSEA), CMIN/DF, Comparative Fit Index (CFI) with the use of SPSS AMOS 23 software. Table 1 presents the model's goodness of fit test results.

Table 1. The assessment of the model's goodness of fit

\begin{tabular}{llllllllll}
\hline CMIN/DF & RMSEA & GFI & IFI & TLI & CFI & AGFI & AGFI/CFI & CR & AVE \\
3.52 & 0.078 & 0.938 & 0.97 & 0.96 & 0.97 & 0.900 & $0.92>0.9$ & $0.89<C R$ & $0.72<$ AVE \\
\hline
\end{tabular}

Source: author's own study developed with SPSS AMOS 23.

Based on the presented test results the CFA model may be assessed as well fit in relation to the gathered data. The reliability level 3.52 can be viewed as high, with the reference $\leq 5$ (Wheaton, 1977). The approximation average error (RMSEA) at 0.078 also meets the reference value below 0.08 according to Steiger and Lind (1980). Measurements of the goodness of fit came close to 1 (Bollen, 1986, 1989) and AGFI/CFI>0.9, which confirms the quality results. AVE (Average of Variance Extracted) is higher than 0.75 for all loadings. Hair, Anderson, Babin, and Black (2010) suggest that an AVE of 0.5 or higher indicates adequate convergence. Cronbach's Alpha test was used to confirm consistency of the constructs measurement model and the alpha coefficient is higher than 0.88 for all constructs which is correct (Francis, 2001; Robinson, Shaver \& Wrightsman, 1991). CR (Composite Reliability) is higher than 0.89 for all loadings, more than the required minimum 0.7 (Hair et al., 2010).

Table 2 presents more details connected with the used scales and their reliabilities, whereas Table 3 confirms discriminant validity (Fornell \& Lacker, 1981). The positive assessment of the model allows us to present the results. 
Table 2. Constructs and scales

\begin{tabular}{|c|c|c|c|}
\hline Construct & Scale & Adapted from & $\begin{array}{l}\text { CFA constructs } \\
\text { validity }\end{array}$ \\
\hline $\begin{array}{l}\text { Tacit } \\
\text { knowledge } \\
\text { sharing (TKS) }\end{array}$ & $\begin{array}{l}\text { I shared my experience } \\
\text { and know-how with team } \\
\text { members of the project } \\
\text { I extracted new knowledge } \\
\text { from the project team } \\
\text { members based on their } \\
\text { experience and know-how } \\
\text { that helped me follow up the } \\
\text { project } \\
\text { I extracted new knowledge } \\
\text { and know-how from experts } \\
\text { and functional co-workers in } \\
\text { my organization that helped } \\
\text { me follow up the project }\end{array}$ & $\begin{array}{l}\text { Gemino, Reich and } \\
\text { Sauer (2015); Park } \\
\text { and Lee (2014); } \\
\text { Hau et al. (2013) }\end{array}$ & $\begin{array}{l}\text { AVE }=0.75 \\
C R=0.90 \\
\text { Cronbach's } \\
\text { Alpha }=0.90\end{array}$ \\
\hline $\begin{array}{l}\text { Trust } \\
\text { (T) }\end{array}$ & $\begin{array}{l}\text { My partners helped me make } \\
\text { critical decisions } \\
\text { My partners could be trusted } \\
\text { completely } \\
\text { I have great confidence in my } \\
\text { partners. }\end{array}$ & $\begin{array}{l}\text { Park and Lee } \\
(2014)\end{array}$ & $\begin{array}{l}\text { AVE }=0.79 \\
C R=0.92 \\
\text { Cronbach's } \\
\text { Alpha }=0.92\end{array}$ \\
\hline $\begin{array}{l}\text { Collaborative } \\
\text { culture } \\
\text { (K) }\end{array}$ & $\begin{array}{l}\text { Problems were discussed } \\
\text { openly to avoid finding } \\
\text { culprits } \\
\text { Collaboration and co- } \\
\text { operation among the } \\
\text { different duties, teams and } \\
\text { departments was encouraged } \\
\text { In general, all teams and } \\
\text { departments are aware of } \\
\text { consumer satisfaction }\end{array}$ & $\begin{array}{l}\text { Perez Lopez, Peon } \\
\text { and Ordas (2004) }\end{array}$ & $\begin{array}{l}\text { AVE }=0.75 \\
C R=0.90 \\
\text { Cronbach's } \\
\text { Alpha }=0.90\end{array}$ \\
\hline $\begin{array}{l}\text { Project } \\
\text { performance } \\
\text { (PP) }\end{array}$ & $\begin{array}{l}\text { I was informed that the } \\
\text { Sponsor of the project was } \\
\text { satisfied with the project } \\
\text { results } \\
\text { I was informed that the } \\
\text { Sponsor of the project was } \\
\text { satisfied with the project } \\
\text { benefits } \\
\text { I received feedback that } \\
\text { the Sponsor of the project } \\
\text { assessed the project positively }\end{array}$ & $\begin{array}{l}\text { Gemino, Reich, } \\
\text { Sauer (2015), } \\
\text { Babbie (2013) }\end{array}$ & $\begin{array}{l}\text { AVE }=0.72 \\
\text { CR=0.89 } \\
\text { Cronbach's } \\
\text { Alpha }=0.88\end{array}$ \\
\hline
\end{tabular}


Table 3. Factor correlation matrix with square root of the AVE on the diagonal

\begin{tabular}{|c|c|c|c|c|c|c|c|}
\hline & AVE & CR & $\begin{array}{l}\text { Cronbach's } \\
\alpha\end{array}$ & K & $T$ & TKS & PP \\
\hline K & 0.75 & 0.90 & 0.90 & 0.87 & & & \\
\hline $\mathrm{T}$ & 0.79 & 0.92 & 0.92 & 0.67 & 0.89 & & \\
\hline TKS & 0.75 & 0.90 & 0.90 & 0.71 & 0.71 & 0.87 & \\
\hline PP & 0.72 & 0.89 & 0.88 & 0.42 & 0.47 & 0.40 & 0.85 \\
\hline
\end{tabular}

Source: author's own study with the use of SPSS AMOS 23.

\section{ANALYSIS/STUDY}

The results point out that collaborative culture and trust are strongly correlated in the context of tacit knowledge sharing and that both these variables have a positive impact on project performance. Referring to path coefficients, the influence of trust on project performance is much stronger than on collaborative culture. Unlike the strong relationship between trust and collaborative culture, tacit knowledge sharing has no significant influence on project performance.

Figure 2 below is a graphical representation of the achieved results.

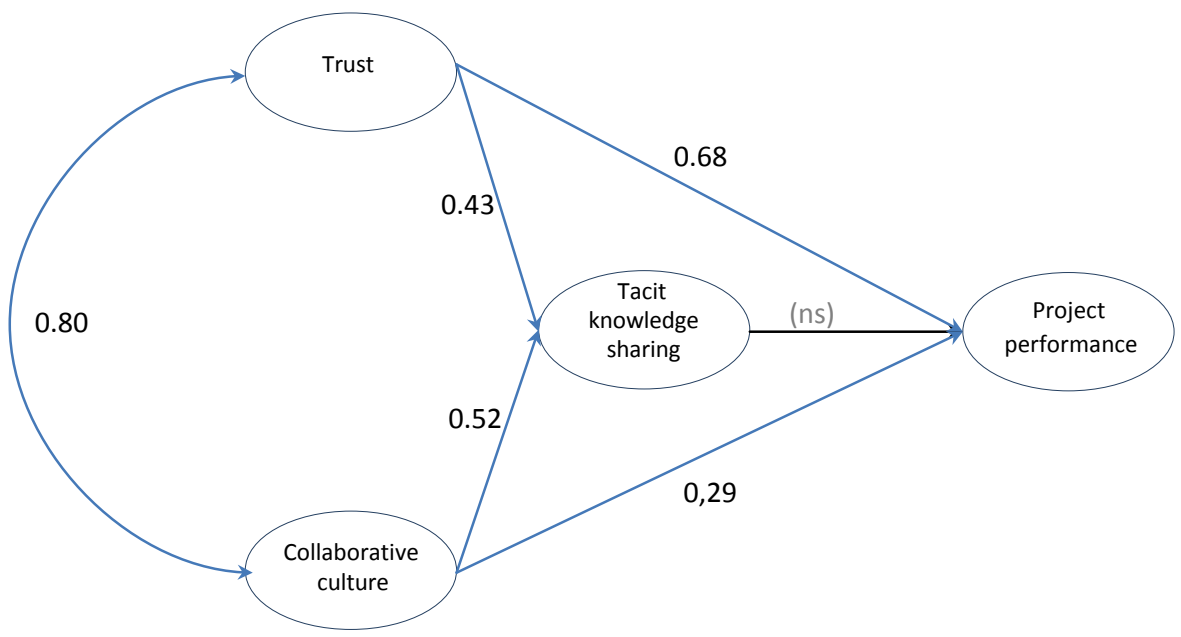

Note: CFA model $p<0.001$, RMSEA $=0.078$, Cronbach's Alpha $>0.88, C R>0.89$ AVE $>0.75$, estimation standardized, ML method, (ns) - not supported.

Figure 2. A graphical representation of achieved results. Source: author's own study with the use of SPSS AMOS 23 
Table 4 below presents a summary of the hypothesis verification referring to the theoretical model presented in Figure 1.

Table 4. Summary of the hypothesis verification

\begin{tabular}{|c|c|c|c|c|c|}
\hline \multicolumn{2}{|c|}{ Hypothesis } & \multirow{2}{*}{$\begin{array}{l}\text { B } \\
.802\end{array}$} & \multirow{2}{*}{$\frac{\text { C.R }}{10.76}$} & \multirow{2}{*}{$\begin{array}{l}\mathbf{p} \\
<0.001\end{array}$} & \multirow{2}{*}{$\begin{array}{l}\text { supported } \\
\text { YES }\end{array}$} \\
\hline $\mathrm{H} 1$ & $\begin{array}{l}\text { Trust and collaborative culture have } \\
\text { a strong, positive correlation. }\end{array}$ & & & & \\
\hline $\mathrm{H} 2$ & $\begin{array}{l}\text { Trust has a positive impact on tacit } \\
\text { knowledge sharing }\end{array}$ & .426 & 6.80 & $<0.001$ & YES \\
\hline H3 & $\begin{array}{l}\text { Trust has a positive impact on project } \\
\text { performance }\end{array}$ & .675 & 8.12 & $<0.001$ & YES \\
\hline $\mathrm{H} 4$ & $\begin{array}{l}\text { collaborative culture has a positive impact } \\
\text { on tacit knowledge sharing }\end{array}$ & .515 & 8.02 & $<0.001$ & YES \\
\hline H5 & $\begin{array}{l}\text { Collaborative culture has a positive impact } \\
\text { on project performance }\end{array}$ & .288 & 3.31 & $<0.001$ & YES \\
\hline H6 & $\begin{array}{l}\text { Tacit knowledge sharing has a positive } \\
\text { impact on project performance }\end{array}$ & -.128 & -1.28 & 0.200 & NO \\
\hline
\end{tabular}

Source: author's own study with the use of SPSS AMOS 23.

\section{DISCUSSION, CONCLUSIONS AND PRACTICAL IMPLICATIONS}

The studies presented in the article were carried out based on a sample including members of project organizations in the construction industry, predominantly men working as project managers (61\% respondents). Therefore, the conclusions of the study dominantly present project managers' point of view.

The aim of the paper was to study collaborative culture and trust in the context of tacit knowledge sharing and present empirical research as a proof of the correlation between the two factors. According to the results presented here and the literature of the subject matter, trust and collaboration between team members are the top concerns to the performance of construction projects. Collaborative relationships, complexity, the uncertainty of environmental conditions, and the pressures of time and budget (which are characteristic of construction projects) increase the need for trust and close cooperation between a project's participants.

The presented study highlights that these two "climate variables" are closely related. This fact leads to a conclusion that collaborative culture and trust co-exist and support each other. From a practical point of view, there is no sense to separate them. For the scientific purpose, it is interesting to measure differences and understand the relationship between these two constructs in different contexts. 
The study of trust and collaborative culture discussed in this work was conducted within the context of tacit knowledge sharing. Figure 2 and Table 4 show that tacit knowledge sharing has no significant influence on project performance. In light of the theoretical justification presented in the Introduction and Conceptual Framework sections, this comes as a surprise. Such an outcome might result from the specific mediatory character of the tacit knowledge sharing variable, more widely described by Kucharska and Dąbrowski (2016). It is worth highlighting that the discussed model is mostly composed of "climate variables" (Baumgartel, Reynolds \& Pathan, 1984), which are presented to be moderators for variables related to management effectiveness. Thus, the achieved results suggest that the tacit knowledge sharing variable is very sensitive and the possibility to observe its influence on project performance depends on other variables used to compose the model's structure. The tacit knowledge sharing variable remains to present itself as a research area worth exploring by scientists.

In relation to the theory presented in the introduction and the conceptual sections, the main new value, based on the presented study is empirical proof that collaborative culture and trust occur together and strongly support each other. Receiving a strong synergy effect as a result of the stimulation, their growth will make it possible to leverage tacit knowledge sharing as an agent contributing to a company's performance.

The study has some limitations which mainly concern the methodological issues. Firstly, the study was conducted on the data coming from the questionnaire survey collected among Polish professionals in the construction industry, where $98 \%$ of the respondents were male and only $2 \%$ were female. Therefore, in reference to the presented sample the conclusions of the study dominantly present a male project manager's point of view from only one industry. Thus, it will be interesting to conduct the same survey based on different industries where women are more widely represented. Results presented for other populations, especially non-European, could bring different conclusions. Secondly, this study has been investigating the structure of the model where antecedents such as trust and collaborative culture impact on tacit knowledge sharing and project performance as outcomes. Lewicki and Bunker (1996) suggest that trust is related to calculusbased and identification-based stages not only knowledge-based as was presented. It may well be that, in the case of other outcomes, the relation between trust and collaborative culture will be presented in a different light and lead to different conclusions. 


\section{References}

Alavi, S.B., \& McCormick, J. (2007). Measurement of vertical and horizontal idiocentrism and allocentrism. Small Group Research, 38(4), 556-564.

Aramo-Immonen, H., Jaakkola, H., \& Linna, P. (2011). Trust building in globalized software engineering: A cultural perspective. Journal of Global Information Technology Management, 14(4), 28-47.

Arpaci, I., \& Baloğlu, M. (2016). The impact of cultural collectivism on knowledge sharing among information technology majoring undergraduates. Computers in Human Behaviour, 56, 65-71.

Artto, K., Kujala, J., Dietrich, P., \& Martinsuo, M. (2008). What is project strategy? International Journal of Project Management, 26(1), 4-12.

Bachmann, R., \& Inkpen, A. C. (2011). Understanding institutional-based trust building processes in inter-organizational relationships. Organization Studies, 32(2), 281-301.

Bakotić, D. (2016). Relationship between job satisfaction and organisational performance. Ekonomska Istraživanja, 29(1), 118-130.

Barczak, G., Lassk, F, \& Mulki, J. (2010). Antecedents of team creativity: An examination of team emotional intelligence, team trust and collaborative culture. Creativity and Innovation Management, 19(4), 332-345.

Barratt-Pugh, L., Kennett, P., \& Bahn, S. (2013). Managing knowledge: The critical role of culture and ownership as a mediator of systems. International Journal of Knowledge Management, 9(2), 20-37.

Baumgartel, H. J., Reynolds, J. I., \& Pathan, R. Z. (1984). How personality and organisational climate variables moderate the effectiveness of management development programmes: A review and some recent research findings. Management \& Labour Studies, 9(1), 1-16.

Beckett, R. C., \& Jones, M. (2012). Collaborative network success and the variable nature of trust. Production Planning \& Control, 23(4), 240-251.

Berasategi, L., Arana, J., \& Castellano, E. (2011). A comprehensive framework for collaborative networked innovation. Production Planning \& Control, 22(5-6), 581-593.

Bollen, K.A. (1989). A new incremental fit index for general structural equation models. Sociological Methods \& Research, 17(3), 303-316.

Brown, S., Gray, D., McHardy, J., \& Taylor, K. (2015). Employee trust and workplace performance. Journal of Economic Behavior \& Organization, 116, 361-378.

Buvik, M.P., \& Rolfsen, M. (2015). Prior ties and trust development in project teams-A case study from the construction industry. International Journal of Project Management, 33(7), 1484-1494.

Buvik, M. P., \& Tvedt, S. D. (2016). The impact of commitment and climate strength on the relationship between trust and performance in crossfunctional project teams: A moderated mediation analysis. Team Performance Management, 22(3/4), 114-138. 
Cai, S., Jun, M., \& Yang, Z. (2010). Implementing supply chain information integration in china: The role of institutional forces and trust. Journal of Operations Management, 28(3), 257-268.

Campbell, D., Stonehouse, G., \& Houston, B. (1999). Business Strategy an Introduction, Butterworth-Heinemann, Oxford.

Cheikhrouhou, N., Pouly, M., \& Madinabeitia, G. (2013). Trust categories and their impacts on information exchange processes in vertical collaborative networked organisations. International Journal of Computer Integrated Manufacturing, 26(1-2), 87-100.

Chen, Y. H., Lin, T.P., \& Yen, D.C. (2014). How to facilitate inter-organizational knowledge sharing: The impact of trust. Information \& Management, 51(5), 568-578.

Chow, I. H. S. (2012). The role of social network and collaborative culture in knowledge sharing and performance relations. SAM Advanced Management Journal, 77(2), 24-33.

Ding, Z., Ng, F., \& Li, J. (2014). A parallel multiple mediator model of knowledge sharing in architectural design project teams. International Journal of Project Management, 32(1), 54-65.

Fawcett, S.E., Jones, S.L., \& Fawcett, A.M. (2012). Supply chain trust: The catalyst for collaborative innovation. Business Horizons, 55(2), 163-178.

Fornell, C., \& Larcker, D. F. (1981). Structural equation models with unobservable variables and measurement error: Algebra and statistics. Journal of Marketing Research, 18(3), 382-388.

Francis, G. (2001). Introduction to SPSS for Windows (3rd ed.). Sydney: Pearson Education Australia.

Gemino, A., Reich, B.H., \& Sauer, C. (2015). Plans versus people: Comparing knowledge management approaches in IT-enabled business projects. International Journal of Project Management, 33(2), 299-310.

Gilbert, J., \& Li-Ping Tang, T. (1998). An examination of organizational trust antecedents. Public Personnel Management, 27(3), 321-338.

Gray, B. (1989). Collaborating: Finding Common Ground for Multiparty Solutions. San Francisco, CA.: Jossey-Bass.

Greiner, M.E., Böhmann, T., \& Krcmar, H. (2007). A strategy for knowledge management. Journal of Knowledge Management, 11(6), 3-15.

Hair, J.F., Anderson, R.E., Babin, B.J., \& Black, W.C. (2010). Multivariate Data Analysis: A Global Perspective. Upper Saddle River, NJ: Pearson.

Harris, F., \& Lyon, F. (2013). Transdisciplinary environmental research: Building trust across professional cultures. Environmental Science \& Policy, 31, 109-119.

Hau, Y.S., Kim, B., Lee, H., \& Kim, Y. G. (2013). The effects of individual motivations and social capital on employees' tacit and explicit knowledge sharing intentions. International Journal of Information Management, 33(2), 356-366.

Hofstede, G.H. (2001). Culture's Consequences: Comparing Values, Behaviors, Institutions and Organizations Across Nations. Thousand Oaks CA.: Sage. 
Inaam, Z., Abderrahman, M., \& Yasmina, H. (2016). A framework of performance assessment of collaborative supply chain. IFACPapersOnLine, 49(12), 845-850.

Khalil, O.E., \& Seleim, A. (2010). Culture and knowledge transfer capacity: A crossnational study. International Journal of Knowledge Management, 6(4), 60-86.

Klijn, E.H., Edelenbos, J., \& Steijn, B. (2010). Trust in governance networks: Its impacts on outcomes. Administration \& Society, 42(2), 193-221.

Kottila, M.R., \& Rönni, P. (2008). Collaboration and trust in two organic food chains. British Food Journal, 110(4/5), 376-394.

Kucharska, W., \& Dąbrowski, J. (2016). Tacit knowledge sharing and personal branding: How to derive innovation from project teams? In A. Aaltio, \& M.T. Eskelinen (Eds.), Proceedings of the 11th European Conference on Innovation and Entrepreneurship (pp. 435-443). Finland, Jyväskylä: The JAMK University of Applied Science.

Kucharska, W., \& Kowalczyk, R. (2016). Trust, collaborative culture and tacit knowledge sharing in project management-A relationship model. In G.S. Erickson \& H.N. Rothberg (Eds.), Proceedings of the 13th International Conference on Intellectual Capital, Knowledge Management \& Organisational Learning (pp. 159-166). New York, USA: Ithaca College.

Kumar, A., \& Paddison, R. (2000). Trust and collaborative planning theory: The case of the Scottish planning system. International Planning Studies, 5(2), 205-223.

Lau, E., \& Rowlinson, S. (2009). Interpersonal trust and inter-firm trust in construction projects. Construction Management and Economics, 27(6), 539-554.

Lefebvre, J.M., \& Shiba, S. (2005). Collaboration and trust in the supply chain: The case of FAVI SA. Supply Chain Forum: An International Journal, 16(2), 90-95.

Lee, P., Gillespie, N., Mann, L., \& Wearing, A. (2010). Leadership and trust: Their effect on knowledge sharing and team performance. Management Learning, 41(4), 473-491.

Lewicki, R.J., \& Bunker, B.B. (1996). Developing and maintaining trust in work relationships. In R.M. Kramer \& T.M. Tyler (Eds.), Trust in Organizations: Frontiers of Theory and Research (pp. 114-139). Thousand Oaks, CA: Sage.

Mach, M., \& Baruch, Y. (2015). Team performance in cross cultural project teams: The moderated mediation role of consensus, heterogeneity, faultiness and trust. Cross Cultural Management, 22(3), 464-486.

Mueller, J. (2014). A specific knowledge culture: Cultural antecedents for knowledge sharing between project teams. European Management Journal, 32(2), 190-202.

Msanjila, S.S., \& Afsarmanesh, H. (2009). On hard and soft models to analyze trust life cycle for mediating collaboration. In Working Conference on Virtual Enterprises (pp. 381-392. Germany: Springer Berlin Heidelberg. 
Msanjila, S.S., \& Afsarmanesh, H. (2011). On modelling evolution of trust in organisations towards mediating collaboration. Production Planning and Control, 22(5-6), 518-537.

Orchard, C.A., Curran, V., \& Kabene, S. (2005). Creating a culture for interdisciplinary collaborative professional practice. Medical Education Online, 10(11), 1-13.

Oyewobi, L.O, Abiola-Falemu, O., \& Ibironke, O.T. (2016). The impact of rework and organisational culture on project delivery. Journal of Engineering, Design and Technology, 14(2), 214-237.

Paliszkiewicz, J.O. (2011). Trust management: Literature review. Management, 6(4), 315-331.

Park, J.G., \& Lee, J. (2014). Knowledge sharing in information systems development projects: Explicating the role of dependence and trust. International Journal of Project Management, 32(1), 153-165.

Pérez López, S., Manuel Montes Peón, J., \& José Vázquez Ordás, C. (2004). Managing knowledge: The link between culture and organisational learning. Journal of Knowledge Management, 8(6), 93-104.

Pishdad-Bozorgi, P., \& Beliveau, Y. J. (2016). Symbiotic relationships between integrated project delivery (IPD) and trust. International Journal of Construction Education and Research, 12(3), 179-192.

Portny, S.E. (2010). Project Management for Dummies. Indiana: John Wiley $\&$ Sons.

Rinehart, R.E., \& Kearl, K. (2016). Auto-, duo- and collaborative-ethnographies: "caring" in an audit culture climate. Qualitative Research Journal, 16(3), $1-16$.

Robinson, J.P., Shaver, P.R., \& Wrightsman, L.S. (1991), Criteria for scale selection and evaluation. In J.P. Robinson, P.R. Shaver \& L.S. Wrightsman (Eds.), Measures of Personality and Social Psychological Attitudes (pp. 1-15). San Diego, CA: Academic Press.

Rutten, W., Blaas-Franken, J., \& Martin, H. (2016). The impact of (low) trust on knowledge sharing. Journal of Knowledge Management, 20(2), 199214.

Smith, R.O. (2008). The paradox of trust in online collaborative groups. Distance Education, 29(3), 325-340.

Steiger, J.H., \& Lind, J.C. (1980). Statistically based tests for the number of common factors. Paper presented at the Annual meeting of the Psychometric Society, lowa City, IA, 758.

Szulanski, G. (1996). Exploring internal stickiness: Impediments to the transfer of best practice within the firm. Strategic Management Journal, 17, 2743.

Taormina, R.J. (2009). Organizational socialization: The missing link between employee needs and organizational culture. Journal of Managerial Psychology, 24(7), 650-676. 
Thimm, H., \& Rasmussen, K. B. 2010. Information support services for intermediation tasks of collaborative networks. Journal of Universal Computer Science, 16(13), 1776-1800.

Thomas, G.F., Zolin, R., \& Hartman, J.L. (2009). The central role of communication in developing trust and its effects on employee involvement. Journal of Business Communication, 46(3), 287-310.

Wallace, N., \& Mello, J. (2015). Collaborative culture: The new workplace reality. Foresight: The International Journal of Applied Forecasting, (39), 31-35.

Wheaton, D.E. (1977). Assessing Reliability and Stability in Panel Models. Sociological Methodology. San Francisco: Jossey-Bass.

Van Oortmerssen, L.A., van Woerkum, C.M., \& Aarts, N. (2014). The visibility of trust: Exploring the connection between trust and interaction in a Dutch collaborative governance boardroom. Public Management Review, 16(5), 666-685.

Yang, L.R., Yen, H.F., \& Chiang, Y.F. (2012). A framework for assessing impacts of leadership competency on police project performance: Mediating role of job satisfaction and moderating role of project type. Policing: An International Journal of Police Strategies \& Management, 35(3), 528550.

Young, T., \& Milton, N. (2011). Knowledge Management for Sales and Marketing. Oxford: CP Chandos Publishing.

Zuo, J., Zillante, G., Zhao, Z.Y., \& Xia, B. (2014). Does project culture matter? A comparative study of two major hospital projects. Facilities, 32(13/14), 801-824.

\begin{abstract}
Polish)
Istnieje wiele teoretycznych i empirycznych dowodów na to, że zaufanie wpływa na kulturę współpracy. Odwrotna zależność również znajduje potwierdzenie w literaturze. Celem niniejszego artykułu jest zbadanie współzależności tych zmiennych w kontekście dzielenia się wiedza niejawnq $w$ organizacji projektowej. W tym celu przeprowadzono badanie na próbie 514 polskich specjalistów wykonujqcych różne funkcje i majqcych różne doświadczenie w zarzqdzaniu projektami w branży budowlanej. Metodq modelowania równań strukturalnych dokonano analizy wzajemnych relacji tych zmiennych. Uzyskane wyniki wskazujq, że istnieje nie tylko silna korelacja między zaufaniem a kulturq współpracy, lecz obie te zmienne charakteryzuje silny wpływ na dzielenie się wiedzq niejawnq. Kluczowq implikacjq praktycznq wynikajqca z badania jest potrzeba stymulowania zarówno kultury współpracy, jak i zaufania. Uzyskanie silnego efektu synergii płynqcej ze współoddziaływania umożliwi pełne wykorzystanie wiedzy niejawnej pracowników celem maksymalizacji wyników organizacji.
\end{abstract}

Słowa kluczowe: zaufanie, wiedza niejawna, kultura organizacyjna, kultura współpracy, zarzqdzanie projektami. 


\section{Biographical note}

Wioleta Kucharska, Ph.D. Eng., holds an Assistant Professor position at the Faculty of Management and Economics, Gdansk University of Technology, Poland. She has 12 years industrial experience in marketing management and was responsible for many market-related processes and projects that strongly required tacit knowledge sharing as a driver of success. She focuses on being effective as a manager and as a teacher, and being innovative and genuine as a scientist. 